\title{
Peculiarities of developing high school students' lexical skills by means of the programmed learning technology
}

\author{
Olga Lebedeva - Svetlana Bykova - Alfiya R. Masalimova - Natalia L. \\ Sokolova - Nina I. Kryukova
}

DOI: $10.18355 / X L .2018 .11 .01 .16$

\begin{abstract}
The purpose of this study is to substantiate theoretically and to test experimentally the effectiveness of the programmed learning technology at the lessons of a foreign language to develop lexical skills of high school students. The article presents the authors' fragments of lessons and sets of exercises with the use of programmed instruction at English classes in Grade 10 to develop students' lexical skills. It is proved that on the stage of forming lexical skills it is viable to develop sets of exercises aimed at memorizing the word, its semantics in the unity with the pronunciation and grammatical form; forming meaningful word combinations with the use of multimedia tools. The authors also found that at the stage of mastering lexical skills it is necessary to do various creative tasks using the Internet. The study proved the effectiveness of the programmed learning technology for the development of students' lexical skills.
\end{abstract}

Key words: programmed learning technologies, information and communication means, development of lexical skills

\section{Introduction}

The use of modern information technologies in teaching is one of the most important and stable trends in the development of the world educational process. In foreign and Russian schools in recent years, computer technology and other information technology tools have been increasingly used in studying most of the subjects, including foreign language lessons. In these conditions, the concepts of programmed learning developed by B.F. Skinner (1954), N.A. Crowder (1968) become actual. The use of a variety of information and communication tools in the programmed learning technology provides focusing on meta-subject results, involving integration of various subject areas with the computer science, which leads to IT development of students' consciousness (Kamalova, Zakirova, 2014; Zakirova, Koletvinova, 2014; Kong, Kayumova, Zakirova, 2017).

The urgency of the work is also conditioned by the growing tension between the requirements of the Federal Law "On Education in the Russian Federation" and the FSES of the second generation to the use of information technologies and technical means while implementing educational programs and the content aspect of teaching and methodological kits that do not correspond adequately to this task. The prerequisite for resolving this contradiction is the teacher's creative work aimed at applying modern educational technologies while developing the lessons' summaries.

The purpose of this article was theoretical substantiation and experimental verification of the effectiveness of the programmed learning technology at foreign language lessons for the development of high school students' lexical skills. The main tasks: to study normative and scientific-methodical literature; to develop summaries of lessons and sets of exercises using the programmed learning technology for the development of high school students' lexical skills; to diagnose the levels of the development of lexical skills before and after the experiment. 


\section{Literature Review}

Many Russian educators turn to the study of the problem of programmed instruction. The teaching manual on pedagogical technologies reveals the structure of the educational program, which clearly sets and regulates the programmed learning algorithm (Kukushkin, 2004; Galushkin, 2015; Li, Pyrkova, Ryabova, 2017; Masalimova et al., 2017). The manual analyzes three types of instructional programs (linear, branched and mixed) and states their advantages and disadvantages.

N.S. Silkina, L.B. Sokolinsky (2016) makes an overview of adaptive models of elearning, believing that its foundation was laid in the 60 s of the 20th century by $\mathrm{N}$. Crowder (1968), who proposed an algorithm for branched programmed learning. The second stage of its development was the use of hypertext and multimedia technologies.

E.I. Vishtenetsky, A.O. Krivosheev (1998) formulate the tasks of using information and communication technologies (ICT) in education, which largely coincide with the tasks of applying the programmed learning technology: to develop students' systematical thinking; to support all types of students' cognitive activities in acquiring knowledge, developing and consolidating skills and abilities; to implement the principle of individualization of the educational process.

In modern teaching practice, including foreign language lessons, the following information and communication tools are most often used: a computer as a training device, an exerciser, a tutor, a simulator of various situations, a means of audio and visual clarity, a printing device for creating hand-outs (Zakharova, 2003); Internet - a global network that allows to open a world of virtual communication and travel, search engines, a huge amount of information from various areas of knowledge (Lvova, 2007); interactive whiteboard allowing to implement the principles of visibility, accessibility, and a differentiated approach to learning, as the whole range of multimedia options is used (Korchazhkina, 2012); MS Power Point program. L.A. Belyaeva and N.V. Ivanova (2008) reveal the advantages of the presentation created in the MS PowerPoint program. Educators also highlight the presentation features that distinguish them from traditional presentation tools: interactivity (Yastrebov, 2007); multimedia information, integrated information; discreteness, software compatibility, availability of technical tools (Belyaeva, Ivanova, 2008).

Model programs for teaching foreign languages in Russia reflect the trends of modern world education. A.N. Shamov (2011) reveals the essence of speech competence, which consists in improving communicative skills in four main types of speech activity, which directly depends on the level of the development of students' lexical skills. E.I. Passov and E.C. Kuznetsova (2002) define the lexical skill as an automated action to select a lexical unit adequately to the idea and its correct combination with other units in productive speech, as well as automated perception and association with meaning in the receptive speech. To improve lexical skills G.V. Rogova (1991) suggests using two categories of lexical exercises aimed at memorizing the word, its semantics in the unity with the pronunciation and grammatical form; forming combinations of words of a semantic character. O.V. Lebedeva and L.S. Maslovets (2015) disclose some features of using the programmed learning technology to improve lexical skills in high school.

Thus, Russian teachers disclose the algorithm of programmed learning technology, the use of a variety of information and communication tools, including foreign language lessons (Golubkova, Masalimova, Birova, 2017; Golubkova, Masalimova, Birova, 2017). However, they pay insufficient attention to the use of programmed learning technology for the development of lexical skills in foreign language lessons. Its important feature in modern conditions is the use of information and communication tools that cause interest and motivation of high school students to a foreign language.

XLinguae, Volume 11 Issue 1, January 2018, ISSN 1337-8384, eISSN 2453-711X 
Various aspects of programmed learning are considered in the works of many foreign researchers. American scientist B.F. Skinner (1954) is considered to be its founder, who presented his concept of programmed learning in his report "The science of learning and the art of teaching." Adhering to behaviorism views, the psychologist developed a program of pedagogical reinforcements for teaching children, where correct reactions were constantly "evaluated" (Skinner, 1977). In the light of the behaviorist theory, he interpreted programmed instruction as a technique designed to maximize the reinforcement associated with the successful management of the environment. "The program is a set of factors that form the topography of reactions and put the behavior under rational management with the help of incentives" (Skinner, 1969).

B. F. Skinner's (1989) training machine was a mechanical predecessor of the computer. The scientist believed that verbal behavior could be taught using initiation, prompting and disappearance of prompts. The students acted in small steps. Their behavior to ensure the success of the action was carefully initiated or prompted, and then received reinforcement. Initiating and prompting data "disappeared" as quickly as possible. The scientist considered creating a situation of success to be a universal stimulus accessible to every teacher.

B. F. Skinner (1989) called the computer an ideal training machine since it is able to model the real life ("operant interactions") in the process of learning, at least schematically. This requires carefully prepared educational programs. B. F. Skinner (1989) was a supporter of the linear method of constructing programmed instruction, which excludes the possibility of errors.

Another American teacher N.A. Crowder (1968), considering the linear construction as the main drawback of Skinner's (1989) concept, developed a method of branched learning and grounded it in the so-called scrambled books, and also created a series of textbooks "TutorText" and the computer program "AutoTutor." Unlike B.F. Skinner (1989), he believed that students have a right to make mistakes in the learning process, so it is important to monitor the quality of mastering the material and providing timely correction. Identifying common errors allows creating a new version of the training program.

The main theoretical provisions of his concept differ somewhat from those proposed by B. F. Skinner: the training course is divided into larger parts (portions, steps), the sizes of which correspond to the volume of the learning topics for the learner to realize the learning goal; a question follows each portion that requires the student to choose the correct answer from among several incomplete or erroneous answers; checking the answer and in case of an error directing the student to additional information concentrated in blocks called "corrective frames"; differentiation of training, since the best students are not directed to the corrective framework to fill in the gaps; - increasing the complexity of educational material on the principle "from simple to complex" in preparing questions and answers to them.

Analyzing concepts of programmed learning, the Polish scientist C. Kupisevich (1986) offers general principles to which he refers: division of the material into small, interconnected parts; making students' activities more dynamic; immediate evaluation of each response; individualization of the pace and content of training; empirical verification of programmed texts.

Let us note that the algorithm of programmed training designated by American scientists allows modern researchers to call it technology. The technological criterion as a key factor in forming modern society is carefully considered by the British scientist F. Webster (2004). He also allocates a spatial criterion. This criterion is especially important at foreign language lessons in order to create an appropriate language environment. Many foreign researchers who use various information and communication tools pay attention to this fact. Their work reveals the role of the computer as an important aid to the teacher (Beaty, 2010); examines main provisions 
of its application in training, control and implementing research (Chapelle, 2001); give practical recommendations to teachers on using the Internet in class (Dudeney, 2007). At the same time, foreign researchers are turning to new interactive methods of teaching foreign languages (Abdyhalykova, 2016, Busse - Krause, 2016) as a part of forming intercultural communication (Lin - Ying, 2014).

Thus, foreign researchers laid the foundations of programmed learning, revealed its advantages and disadvantages, substantiated its principles and the application technology. In the works of modern authors, the main attention is paid to the use of information means of instruction, but they are not associated with the peculiarities and the technology of programmed learning.

\section{Research Methodology}

\subsection{Materials and methods}

- Testing aimed at identifying students' levels of the development of lexical skills in the topics studied, before and after the experiment.

- Questioning, including self-assessment of the students' levels of the development of lexical skills and their relation to the use of ICT in English classes.

- Monitoring students' monological and dialogical speech using the studied vocabulary and assessing them according to a five-point system at English lessons.

- Analysis and synthesis of normative documents, the study of psychological, pedagogical and methodological literature, content analysis of the teaching materials Enjoy English for Grade 10 by M.Z. Biboletova, E.E. Babushis and N.D. Snezhko (2017abcd), allowed to develop an algorithm for applying the programmed learning technology for developing lexical skills, and the corresponding exercises.

\subsection{Stages of research}

The study included three stages:

The first stage - the search-theoretical stage - implied understanding and formulating research problems; defining the goal, the hypothesis of the study; drawing up a research plan; defining indicators and levels of students' lexical skills.

The second experimental stage involved the content analysis of the English textbook; revealed the possibilities of the textbook for programmed learning technology; summaries of the lessons were compiled. The results of the pedagogical experiment including working out lessons with the algorithm of programmed learning were analyzed.

The third stage is the generalization of the research results. A qualitative and quantitative analysis of the results and their theoretical substantiation were carried out.

\subsection{Research procedures and participants}

\subsubsection{The base of research}

Grade 10 "B" of municipal secondary school №16 (Kirov), which was divided into 2 subgroups: one was experimental, the other became the controlled one. The experiment was conducted during the 2014-2015 academic year.

\subsubsection{Evaluation Criteria}

To assess the development of high school students' lexical skills we used the indicators of the European system of levels of the language competence: understanding (listening and reading); speaking (dialogue and monologue); writing; range; accuracy; fluency; interaction; cohesion of speech (European School of Language Competence).

Low level - the student understands individual words and simple phrases in clearly spoken speech and text; can ask simple questions and answer them within the framework of familiar topics, but makes mistakes; makes up a story on familiar

XLinguae, Volume 11 Issue 1, January 2018, ISSN 1337-8384, eISSN 2453-711X 
topics, using simple phrases, but with mistakes; makes mistakes in writing; has a small stock of words and phrases; uses vocabulary in simple grammar constructions; no fluency of speech, stops to find right words, expressions, to correct mistakes; communication is limited to personal matters within familiar topics; cohesion of speech is low.

Intermediate level - the student understands the main content, catches unfamiliar vocabulary in clearly spoken speech; understands the main content of the text, but finds it difficult to understand unfamiliar words; can support the conversation and build his speech utterance, using simple phrases within familiar topics; uses studied constructions, word combinations and standard speech patterns in dialogues and monologues; expresses an idea with short phrases, a low rate of speech; knows how to answer questions, follows the thought of the partner, but cannot independently support the conversation; for the sake of consistency and cohesion of utterances, simple conjunctions are widely used.

High level - understands the content of oral and written speech; can participate in the dialogue without preparation; expresses his opinion in a monologue; can write messages, essays, reports; vocabulary allows to participate actively in the conversation; correctly uses familiar constructions; the rate of speech is quite high; able to start, support and finish the conversation; speech construction is cohesive and logical.

\subsubsection{Progress and description of the experiment}

To study the foreign language in Grade $10 \mathrm{~B}$ we used the teaching materials Enjoy English for grade 10 by M.Z. Biboletova, E.E. Babushis, and N.D. Snezhko (2017 abcd), which consist of a Student's Book Enjoy English (2017c); Teacher's Book (methodical guide for the teacher on the use of the textbook) (2017d); Workbook No. 1 (2017a); Workbook No. 2 - "Test work" (2017b); audio applications (CD MP3).

The work on the development of lexical skills using the programmed learning technology included three stages, each of which has its own specific features in senior classes.

1. Introducing the new lexical material (introduction and semantisation of lexical units). In senior classes, the main way of semanticizing new vocabulary is uninterpreted, since it is important to form students' language and speech assumption. Demonstrating visual material gives a basis for developing abstract thinking in order to establish the peculiarities of the words used in speech, their compatibility with other words and grammatical design independently, without the teacher's explanation. 2. Forming lexical skills through drilling lexical units. The specificity of the work on the vocabulary in senior classes does not allow us to make full use of conditionally speech exercises since at this stage of training the development of skills is in the first place. Therefore we used categories of lexical exercises offered by G.V. Rogova (1991).

3. Mastering lexical skills through the use of lexical units. The peculiarity of this stage is an approach to speech because the ability to communicate in a foreign language is the main objective of training. Students are offered to perform various creative assignments using information and communication tools (write an e-mail, a message to the forum, discuss important issues in the dialogue according to the plan, compose a monologue on the proposed topics). Work on these assignments in the relevant sections of the textbook does not only contributes to the improvement of lexical skills and the development of skills in monologues, dialogue, and written speech but also leads to the social self-determination of the individual, the formation of value orientations. 


\section{Results and Discussions}

\subsection{The ascertaining experiment}

During the ascertaining experiment of each group, a test was proposed to establish the level of the development of students' lexical skills. The results are clearly shown in the diagram.

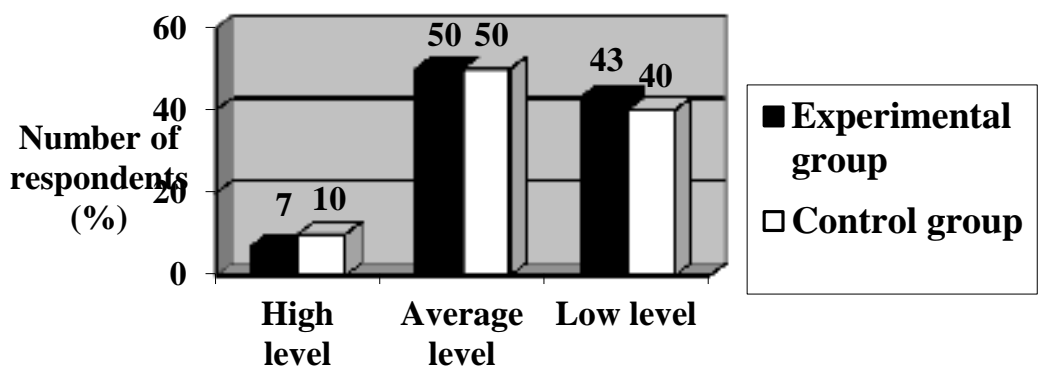

\section{Levels of the Development of lexical skills}

Figure 1: Diagram of levels of the development of high school students' lexical skills on the ascertaining stage

The diagram shows that lexical skills of the experimental group are developed at a high level in $7 \%$ of the pupils, at the average level - in $50 \%$ of the students, at a low level in $43 \%$ of the students. In the control group, $10 \%$ of students have a high level of lexical skill development, $50 \%$ - an average level, $40 \%$ - a low level. Consequently, students of both groups have approximately the same level of the development of lexical skills.

\subsection{The forming stage of the experiment}

To organize experimental training exercise sets were developed using the programmed learning technology, the purpose of which was to form and improve lexical skills. According to the peculiarities of forming lexical skills, where tasks require the use of the only correct in this particular case lexical unit, we selected a linear method for constructing the algorithm.

During the forming stage of the experiment, lessons were conducted on the following topics: "Where does Time Go?", "Exploring Your Family," "Family Room." The most frequently used tools were a presentation created in MS PowerPoint, a projector, a computer, the Internet network, a CD with audio and video recordings. Here is a fragment of one of the lessons.

Unit 1. Start anew; Section 5. Where does time go?

The purpose of the lesson is to master the speech competence (developing skills of exploratory reading and reading for detail).

Objectives: 1) educational: development of speaking skills, the formation of lexical skills; 2) educative: forming a responsible attitude towards learning, attention, respect

XLinguae, Volume 11 Issue 1, January 2018, ISSN 1337-8384, eISSN 2453-711X 
for the opinions of others; 3) developing: the development of memory, thinking, linguistic guess, creative imagination, interest to the English language.

Lexical units: to calm down, to break, to break, to break, to break, to break, to break, to be hard to believe, to relieve stress.

Speech material: The commentary from TeenInk magazine.

Lesson equipment: a computer, a projector, a screen, MS Power Point presentation.

The algorithm for using the programmed learning technology at the lesson is presented in Figure 1.

In this fragment of the lesson, the text acts as a means of forming lexical skills and developing speaking skills

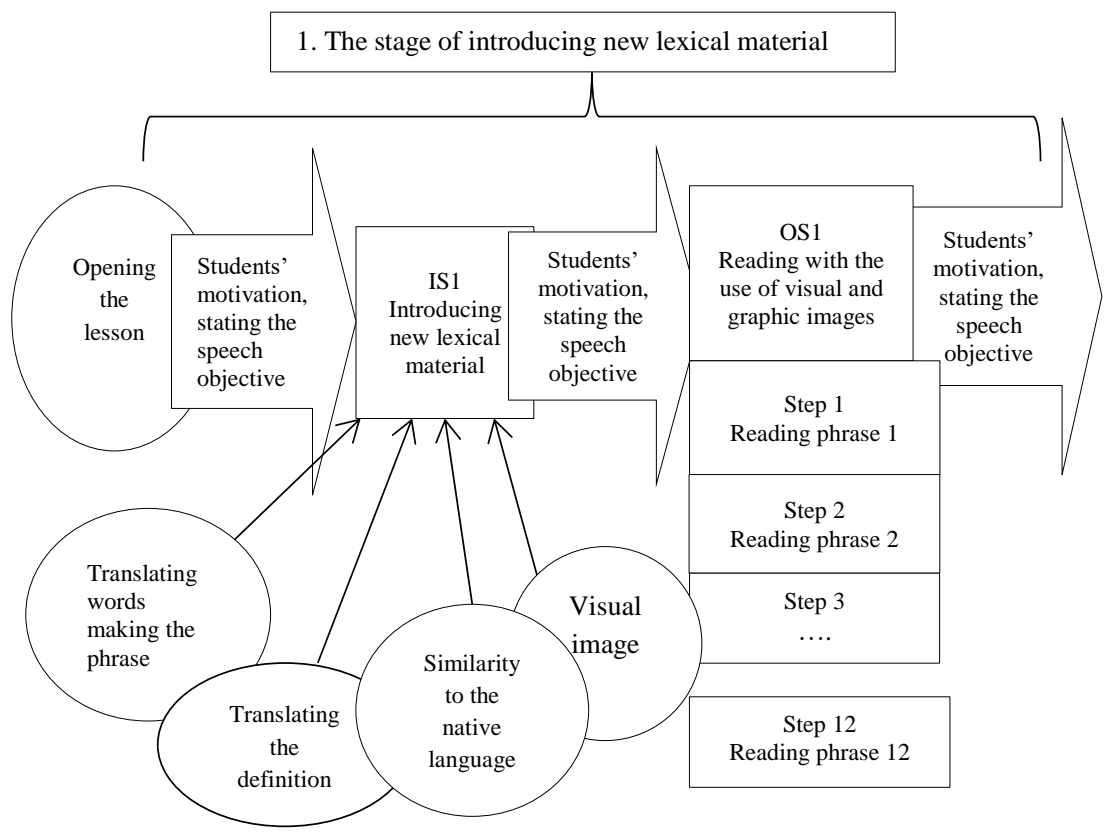









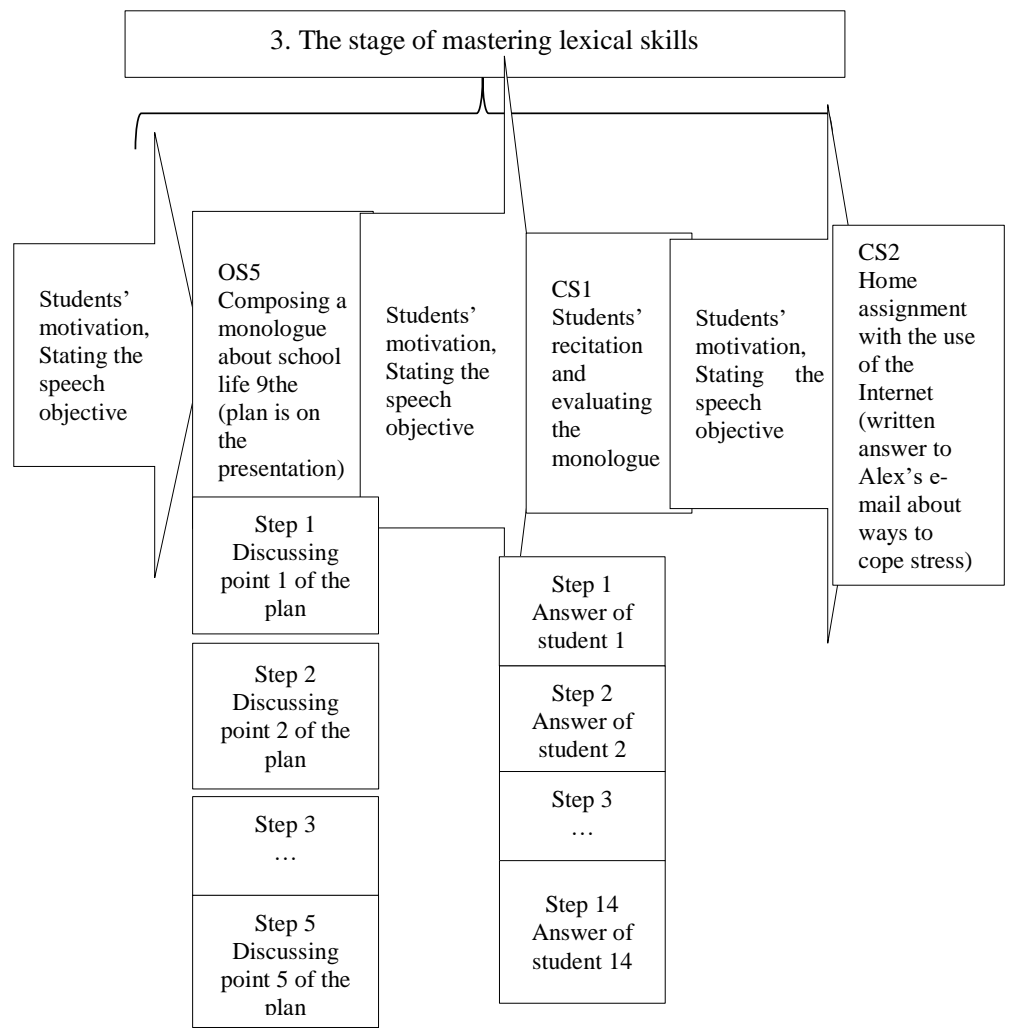

Figure 1: Algorithm of a fragment of the lesson

\section{The stage of introducing new lexical material}

Students' motivation, stating the speech objectively

You are pupils and have different problems at school. And I can say that all students have these difficulties. Today we are to read a commentary from a teen magazine and get to know what problems teenagers in the USA have. But first of all, we'll learn some new words and phrases. Please, look at the screen.

Information slide 1 includes the presentation and display of lexical units functioning in the speech together with visual support typified by MS PowerPoint. The students' task is to guess the meaning of a lexical unit using the image, based on the translation of words included in the phrase, the similarity to the native language, or through a commentary. Students get acquainted with the graphic and grammatical form of the word and guess its meaning in the context, for example:

- to calm down - to become quiet and relaxed after you have been angry, excited, nervous, or upset;

- to concentrate on something - to give most of your attention or effort to one thing (focus on).

Operational slide 1 includes tasks to simulate new words in the course of repeating after the teacher.

\section{The stage of forming lexical skills}

On this stage, operational slides include students' performing training exercises under the teacher's guidance.

Operational slide 2. 
Students read out sentences with phrases from the text, paying attention to their graphic and grammatical form and meaning. All sentences from the text are duplicated on the presentation slide along with the images, which helps to remember new lexical units better and faster:

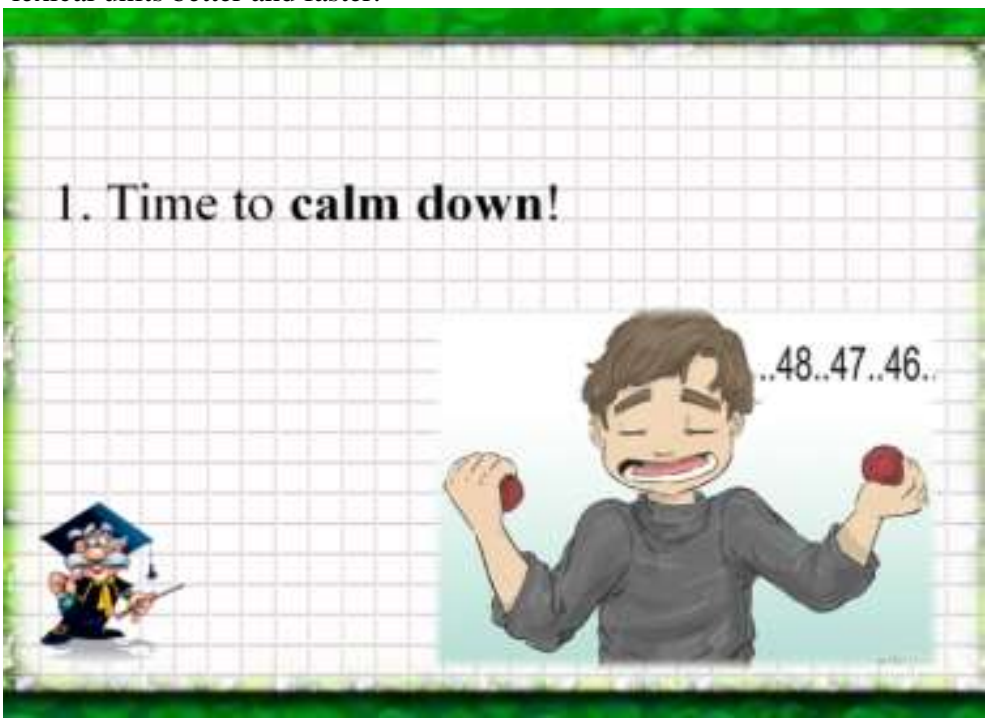

Figure 1: Step 1 - reading and translating lexical unit 1.

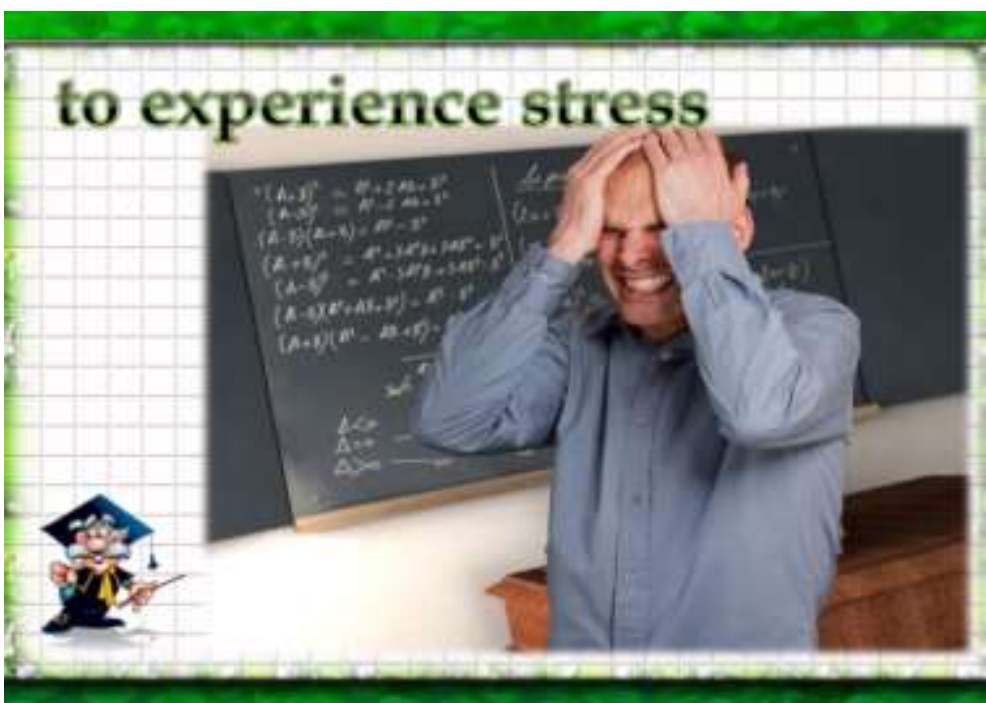

Figure 2: Step 3 - reading and translating lexical unit 3.

Almost all of us as teenagers experience stress during our high school career.

Operational slide 3.

Students fill in the gaps using new lexical units. Images help to recall necessary phrases.

XLinguae, Volume 11 Issue 1, January 2018, ISSN 1337-8384, eISSN 2453-711X 


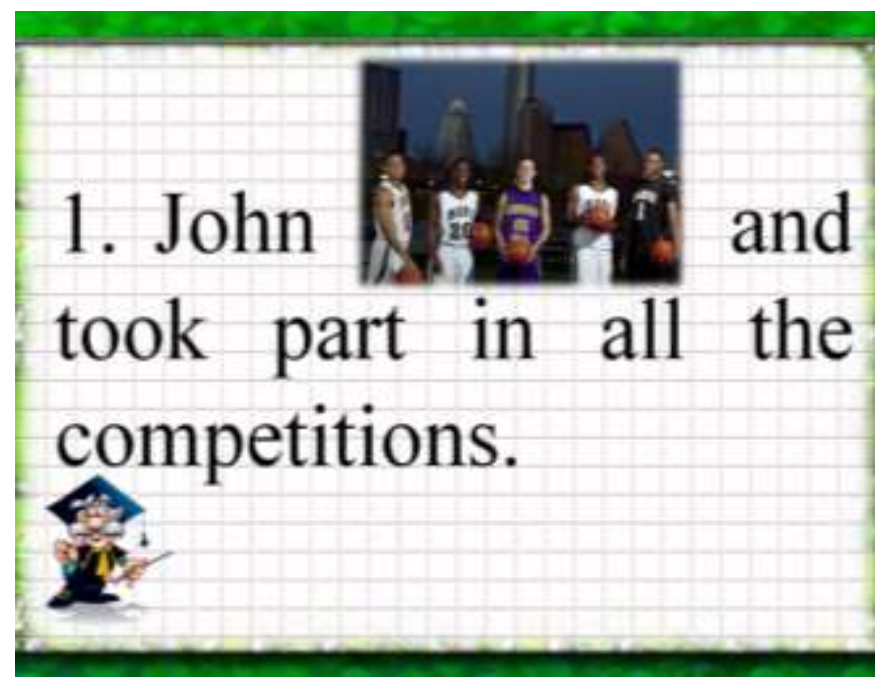

Figure 3: Step 1 - filling in the gaps in Sentence 1.

Key: had an active school career



Figure 4: Step 4 - filling in the gaps in Sentence 4.

Key: concentrating on

Operational slide 4.

Students answer the teacher's questions using new lexical units. For them to avoid difficulties and to remember new words better questions and images are displayed in the presentation.

5. How often do you take a break while doing your homework?

12. Can you give us any advice how to relieve stress?

Further, students work with the text.

III. The stage of mastering lexical skills.

Students' motivation, stating the speech objectively

Well, now you know how teenagers in the USA cope with stress at school. But we should find out how teens in Russia can relieve it. For it, make up a story about 
yourselves and give some advice about this problem. At the screen you can see a plan which will help you:

1. Why do pupils experience stress at school?

2. How to calm down and concentrate on studies?

3. How to combine an active school career with working toward good marks?

4. What to do in order to prepare yourself for colleges and universities?

5. How to relieve stress?

Operational slide 5.

Students make monologues about their school life using the plan and new lexical units.

Control slide 1 includes students' recitation and a reasoned assessment of their responses.

Control slide 2 students' homework: writing an e-mail about their problems and ways to deal with stress.

During the homework assignment, the students use the studied words and the Internet, which increases their motivation and interest in the subject.

Thus, conducting lessons using the programmed learning technology contributed to the activation of cognitive activity of students. The questioning of high school students showed that $93 \%$ of the students liked the classes; all respondents would like to attend such lessons; $71 \%$ of students quickly learned lexical units in these classes.

\subsection{The control stage of the experiment}

After the completion of the experimental training in the experimental and control groups of Grade10 B, a test was again proposed to reveal the level of the development of their lexical skills.

Comparing the results of the ascertaining and control experiments showed that the level of the development of lexical skills of the experimental group students increased: the number of students with a high level of lexical skills in the experimental group increased by $22 \%$, with an average level - by $14 \%$, and with a low level decreased by $36 \%$. In the control group, the indices changed insignificantly only one student showed progress in mastering the lexical material. In the control group, the number of students with an average level of the development of lexical skills increased by $10 \%$.

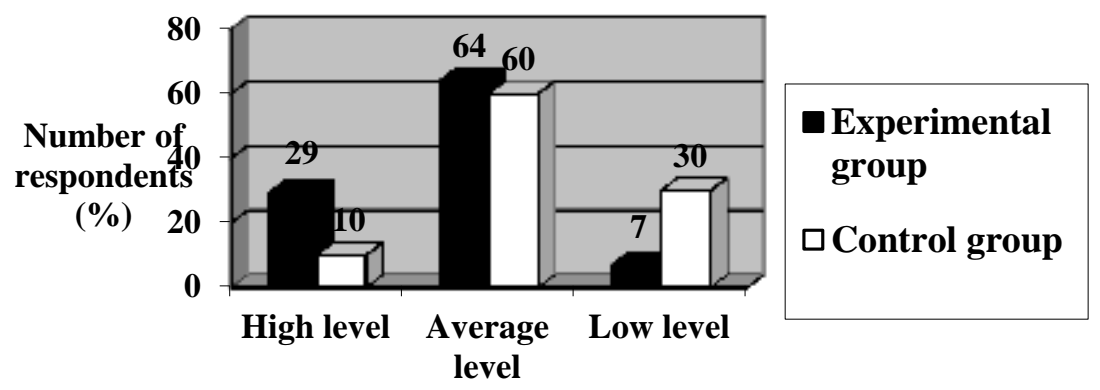

XLinguae, Volume 11 Issue 1, January 2018, ISSN 1337-8384, eISSN 2453-711X 
Figure 5: Diagram of levels of the development of high school students' lexical skills after the experiment

The effectiveness of programmed learning technology is confirmed by the qualitative analysis of the development of students' lexical skills who were on different levels. Pavel P., with a low level of lexical skills on the stage of the ascertaining experiment, had a small stock of lexical units, refused to work at the lesson, could not answer elementary questions. He did not do his homework; he did not remember new words at the lesson. He did not understand the content of oral and written speech with the new lexical material. He had difficulties with the semantics of new vocabulary. His utterances were short, without new words, with a large number of language and phonetic mistakes. The rate of speech was slow. Written assignments were not always logical, with limited use of words, the norms of language were not always observed.

After conducting the forming experiment, Paul P. reached an average level of the development of lexical skills. He began to participate in conversations with the teacher and classmates in class and do homework. The rate of reading was not high, but he began to understand the main content of the reading, had difficulties in understanding some unfamiliar words. During listening, he understood half the text, almost all the words introduced in the lesson. The speech utterances became more coherent and consistent, with most of the new vocabulary, but had some mistakes in its use. The speech rate was not high enough; the pronunciation was influenced by the native language. There were some inaccuracies in the use of words in written speech.

Ksenia S. had an average level of lexical skills at the stage of the ascertaining experiment. At the lessons, she tried to keep up the conversation with the teacher, answered questions, but did not always use new lexical units, made mistakes in the use of new words or replaced them with previously studied vocabulary. While reading and the oral speech she understood the main content of the text, could highlight the main idea. There were difficulties in understanding some unfamiliar words and new vocabulary. While listening she understood only $2 / 3$ of the information, there were difficulties in listening comprehension of phrases with unfamiliar words. The utterances in monologues and dialogues were somewhat inconsistent, the rate of speech slowed down, she used a fairly large amount of language tools. In written speech, in some cases, there were spelling mistakes.

After conducting the forming experiment, the development of Ksenia S.'s lexical skills rose to a high level. She tried to express her opinion correctly using new words. In homework there were practically no mistakes, new vocabulary was used. She had no difficulty in understanding the content of the spoken or read the text. In the speech utterances, the range of linguistic means was quite wide. The rate of speech was high, fluent, with good pronunciation. The written works followed the basic rules for text formatting. She showed knowledge of a large vocabulary stock, logic, and coherence of speech.

Thus, a qualitative and quantitative analysis of the results of experimental verification of the use of programmed learning technology showed an increase in the levels of the development of high school students' lexical skills.

The conducted study showed that the teachers do not have unanimity on the evaluation of programmed learning. The training manual (Kukushkin, 2004) gives different interpretations of this type of training: the process of compiling an orderly sequence of actions for computers, as cybernetic didactics, as a special kind of independent work. In the light of the behaviorism theory B.F. Skinner (1969) treats programmed learning as rational management of speech behavior with the help of stimuli. Based on the analysis of different points of view, we understand programmed learning as the optimal management of students' cognitive activity. A question concerning the principles of a linear and branched training program is also under discussion. O. N. Crowder (1968) criticizes B.F. Skinner's (1954) concept of linear 
learning for the lack of a corrective program and insufficient differentiation of training. However, it should be noted that B.F. Skinner did not consider differentiation of training as a principle, but referred it to the advantages of programmed learning: We consider it reasonable to use the linear program of instruction at the stages of introducing vocabulary and forming lexical skills, and leave the branched program for the stage of their mastering.

In the course of experimental work, we came to the conclusion that the use of the programmed learning technology at foreign language lessons in modern conditions has its own peculiarities determined by the development of the information society, as well as by the specifics of the development of high school students' lexical skills and interests. On the stage of introducing new lexical material for the development of high school students' linguistic and speech assumption, an uninterpreted way of semanticizing new vocabulary allows using an MS PowerPoint presentation. On the stage of forming lexical skills it is rational to develop sets of exercises aimed at memorizing the word, its semantics in the unity with the pronunciation and grammatical form; forming combinations of words of a semantic character with the use of multimedia tools. On the stage of mastering lexical skills, various creative assignments with the use of the Internet cause greater interest of high school students.

\section{Conclusion}

In the course of the research, an algorithm was developed to use the programmed learning technology on several topics of the tutorial Enjoy English for Grade 10 by M.Z. Biboletova, E.E. Babushis, and N.D. Snezhko (2017c) to master high school students' lexical skills. Information slide corresponds to the stage of introducing new vocabulary and its perception. The operational slide is present on all stages of the work with new lexical units while goal-oriented doing reproductive, training and creative exercises. The control slide appears when checking and evaluating the development of lexical skills. The system of multiple sequential operations that a student makes to acquire and store information promotes its memorization and practical application. Multiplicity and sequence of repetition of lexical units acquired at the stage of introducing the new lexical material, in new exercises on the following stages lead to forming and mastering lexical skills.

The developed sets of exercises with the use of a computer, a screen, a projector, MS PowerPoint presentations, and the Internet make it possible to create a favorable environment for the development of high school students' communicative competence in a foreign language. They memorize new lexical units faster, use them more correctly and more often in their monologues and dialogues, they have less difficulty in learning new vocabulary during reading and listening. Students' speech becomes more literate, more fluent, with fewer mistakes that make communication difficult, the language and speech assumption develops.

The programmed learning technology, supplemented by the use of information and communication tools, promotes students' interest, activates their cognitive activity and motivates them to the practical use of a foreign language.

\section{Acknowledgments}

1. The work is performed according to the Russian Government Program of Competitive Growth of Kazan Federal University.

2. The work was carried out with the financial support of the Ministry of Education and Science of the Russian Federation under the Peoples' Friendship University of Russia (RUDN University) Program "5-100" among the world's leading research and educational centers for 2016-2020. 


\section{Bibliographic references}

ABDYHALYKOVA, A. 2016. Innovative methods of foreign languages teacher. In: Modern journal of language teaching methods, vol. 6, n. 3, pp. 11-17. ISSN 22516204.

BEATY, K. 2010. Computer-assisted Language Learning. Longman. Pearson Education. ISBN 13-9781408205006. ISBN 10-1408205009.

BELYAEVA, L. A. - IVANOVA, N. V. 2008. PowerPoint presentation and its possibilities in teaching foreign languages. In: Journal of Foreign languages at school, vol. 4, pp. 36-41. ISSN 0130-6073.

BIBOLETOVA. M.Z. - BABUSHIS. E.E. - SNEZHKO N.D. 2017a. Enjoy English 10 class. Workbook 1. Publishing center: Drofa. ISBN 978-5-86866-434-2.

BIBOLETOVA. M.Z. - BABUSHIS. E.E. - SNEZHKO N.D. 2017b. Enjoy English 10 class. Workbook 2. Publishing center: Drofa. ISBN 978-5-86866-484-7.

BIBOLETOVA. M.Z. - BABUSHIS. E.E. - SNEZHKO N.D. 2017c. Enjoy English 10 class. Student's Book. Publishing center: Drofa. ISBN 978-5-17-090259-0.

BIBOLETOVA. M.Z. - BABUSHIS. E.E. - SNEZHKO N.D. 2017d. Enjoy English 10 class. Teacher's Book. Publishing center: Drofa. ISBN 978-5-408-00779-0.

BUSSE, V. - KRAUSE, U.M. 2016. Instructional methods and languages in class: A comparison of two teaching approaches and two teaching languages in the field of intercultural learning. In: Journal of learning and Instruction, vol. 42, pp. 83-94. ISSN 0959-4752.

CHAPELLE, C.A. 2001. Computer Applications in Second Language Acquisition: foundations for teaching, testing and research. Cambridge: University Press. ISBN 0-521 626374. ISBN 0-521 0626463.

CROWDER, N.A. 1968. On the differences between linear and branched programming. Programmed instruction abroad: Sat. Articles. Ed. I.I. Tikhonov. pp. 58-67. Available online: http://evgenysavin.ru/load/6-1-0-35

DUDENEY, G. 2007. The Internet and the Language Classroom: a practical guide for teachers. Cambridge: University Press, Pp. v. + 171. ISBN 978-0-521-68446-0, 978-0-521-78373-6.

GALUSHKIN, A.A. 2015. Education in the Field of National Information Security in the Russian Federation and Abroad. In: Journal of Computer Science, vol. 11, n. 10, 988-994. ISSN Print: 1549-3636. eISSN 1552-6607.

GOLUBKOVA, O.N. - MASALIMOVA, A.R. - BIROVA, J. 2017. The Development of Sociocultural Competence in Future Translators Via the Methodology of Culture-Oriented Interpretation of English Language Fictional Texts. In: Man In India, vol. 97, n. 14, pp. 73-83. ISSN 00251569.

KAMALOVA, L.A. - ZAKIROVA, V.G. 2014. Technique of comparative studying of the Russian and Tatar national fairy tales at modern elementary school in a context of dialogue of cultures. In: Middle - East Journal of Scientific Research, vol. 21, n. 1, pp. 33-37. ISSN: 1990-9233

KAZAKOV, A.V. - ZAKIROVA, V.G. - BIROVA, J. 2017. Modeling the Process of Forming Social and Cultural Competence among Students of Linguistics Faculty. In: Man In India, vol. 97, n. 14, pp. 291-305. ISSN 00251569

KONG, Y. - KAYUMOVA, L.R. - ZAKIROVA, V.G. 2017. Simulation Technologies in Preparing Teachers to Deal with Risks. In: Eurasia Journal of Mathematics, Science and Technology Education, vol. 13, n. 8, pp. 4753-4763. ISSN $13058215,13058223$.

KORCHAZHKINA, O.M. 2012. The specific use of an interactive Board at lessons of a foreign language when performing creative tasks. In: Journal of Foreign languages at school, vol. 6, pp. 27-32. ISSN 0130-6073.

KORNILOVA, V.I. - MAGSUMOV, T.A. - SHAKIROV, R.R. Female Teachers Training in Educational Grades of Women's Gymnasia in Kazan in the Last Third of the XIX - Early XX Centuries. European Journal of Contemporary Education, 
2016, Vol. 16, n. 2, pp. 217-228. DOI: 10.13187/ejced.2016.16.217

KUKUSHKIN, V. S. 2004. Pedagogical technologies : textbook for students of pedagogical specialties. Rostov n/D: Publishing center March; Phoenix. ISBN 5 241-00145-X.

KUPISEVICH, C. 1986. Fundamentals of General didactics. Moscow: Higher school. LEBEDEVA, O.V. - MASLOVETS, L.S. 2015. Information and Communication Technologies in programmed learning as a means of developing lexical skills. In: Journal of Foreign languages at school, vol. 9, pp. 33-38. ISSN: 0130-6073.

LI, N. - PYRKOVA, K.V. - RYABOVA, T.V. 2017. Teaching Communication Skills and Decision-Making to University Students. In: EURASIA Journal of Mathematics, Science and Technology Education, vol. 13, n. 8, pp. 4715-4723. ISSN: $13058215,13058223$.

LIN, L. - YING, Z. 2014. The Application of Constructivism to the Teaching of Intercultural Communication. In: English Language Teaching, vol. 7, n. 5. ISSN 1916-4750, 1916-4750.

LVOVA, O.V. 2007. Using information and communication technologies to organize and carry out project activities (in teaching foreign languages at school). Ph.D. thesis. Moscow.

MASALIMOVA, A.R. - LEVINA, E.Y. - PLATONOVA, R.I. - YAKUBENKO, K.Yu. - MAMITOVA, N.V. - ARZUMANOVA, L.L. - GREBENNIKOV, V.V. MARCHUK, N.N. 2017. Cognitive Simulation as Integrated Innovative Technology in Teaching of Social and Humanitarian Disciplines. In: EURASIA Journal of Mathematics, Science and Technology Education, vol. 13, n. 8, pp. 4915-4928. ISSN: $13058215,13058223$.

PASSOV, E.I. - KUZNETSOVA, E.C. 2002. The Formation of Lexical Skills. Voronezh: KNOW Interlingua. ISBN 5-93757-008-1.

ROGOVA, G.V. - RABINOVICH, F.M. - SAKHAROVA, T.E. 1991. Methods of teaching foreign languages at school. Moscow: Enlightenment. ISBN 5-09-0010293.

SHAMOV, A.N. 2011. Cognitive activity of students and formation of lexical skills of different types of speech activity. In: Journal of Foreign languages in school, vol. 9, pp. 10-17. ISSN 0130-6073.

SILKINA, N. S. - SOKOLINSKY, L.B. 2016. Review of adaptive models of elearning. In: Bulletin of SUSU. Series: Computational mathematics and computer science, vol. 5, n 4, pp. 61-76. ISSN 2410-7034.

SKINNER, B F. 1969. Contingencies of Reinforcement. A Theoretical Analysis. Available online: www.klex.ru/lpe/.

SKINNER, B.F. 1989. The School of the Future. Available online: www.klex.ru/lpe/. SKINNER, B.F. 1954. The science of Learning and the Art of Teaching. Cambridge. Programmed instruction abroad: Sat. Articles. Ed. I.I. Tikhonov. pp. 32-46. Available online: http://evgenysavin.ru/load/6-1-0-34

SKINNER, B.F. 1977. Why I am not a cognitive psychologist. Available online: www.klex.ru/lpe/.

VISHTENETSKY, E.I. - KRIVOSHEEV, A.O. 1998. The information technology in education and training. In: Journal of Information technology, n. 2, pp. 32-37. ISSN 1684-6400.

WEBSTER, F. 2004. Theory of information society. Moscow: Aspect Press Publ. ISBN 5-7567-0342-X, 0-415-28201-2.

YASTREBOV, L.L. 2007.Create multimedia presentations in MS PowerPoint 2002. In: Journal of Questions Internet education, n. 47, pp. 8-21.

ZAKHAROVA, I.G. 2003. Information technologies in education: Textbook for students of higher pedagogical educational institutions. Moscow: Publishing Center «Academy.» ISBN 5-7695-1239-3.

XLinguae, Volume 11 Issue 1, January 2018, ISSN 1337-8384, eISSN 2453-711X 
ZAKIROVA, V.G. - KOLETVINOVA, N.D. 2014. The paradigm of future primary school teachers' vocational training. In: Life Science Journal, vol. 11, n. 4, pp. 441447. ISSN 1097-8135 (Print) / ISSN 2372-613X (Online).

Words: 6476

Characters: 42818 (23,79 standard pages)

Prof. Olga V. Lebedeva, Dr. of Education

Faculty of pedagogy and psychology

Department of pedagogy

Vyatka State University

36 Moskovskaya Str.

610000 Kirov

Russia

oven1234@yandex.ru

Assoc. Prof. Svetlana S. Bykova, PhD

Faculty of pedagogy and psychology

Department of pedagogy

Vyatka State University

36 Moskovskaya Str.

610000 Kirov

Russia

vetabykova@mail.ru

Prof. Alfiya R. Masalimova, Dr. of Education,

Institute of Psychology and Education

Kazan (Volga region) Federal University

18 Kremlyovskaya Str.

420008 Kazan

Russia

alfkazan@mail.ru

Assoc. Prof. Natalia L. Sokolova, PhD in Philology

Head of the Institute of Foreign Languages

RUDN University (Peoples' Friendship University of Russia)

6 Miklukho-Malkaya Str.

117198, Moscow

Russia

oushkate@mail.ru

Prof. Nina I. Kryukova, Dr. of Law,

Department of State-Legal and Criminal Law Disciplines

Plekhanov Russian University of Economics

Moscow, Russia

36 Stremyannyi Pereulok Str.

115093 Moscow

Russia

ninari68@mail.ru 